\title{
Die stryd oor die opstanding aan die Teologiese Fakulteit by UP. 'n Gesprek met Prof Julian Müller
}

A S van Niekerk

(Universiteit van Pretoria)

\section{ABSTRACT \\ The dispute about the resurrection at the Faculty of Theology at UP: A discussion with Prof Julian Müller}

In recent years some of the lecturers at the Faculty of Theology at the University of Pretoria were confronted with the question whether they believed in the historical and physical resurrection of Jesus. This article focuses on a book on the resurrection in which one of these lecturers, professor Julian Müller of Practical Theology, responds to this question. He refuses to answer with a simple "yes", because he feels the question originates from a fundamentalist and modernistic theology, in which the aim is to take control of the truth. He offers a postmodern interpretation. In this article an effort is made, from the viewpoint of Missiology, to understand his views as he wishes them to be understood, and to respond to it. In Missiology, through the theological rediscovery of Biblical eschatology, the physical and historical resurrection of Jesus has become of central importance again, also in a postmodern paradigm. In conclusion, an effort is made to understand the role of our Faculty of Theology within our Southern African context.

\section{INLEIDING}

Botsende teologiese strominge het die afgelope jare heelwat spanning veroorsaak in die NG Kerk. Teologiese strominge het ' $n$ middelpuntvlietende krag geword. Indien die NG-familie verenig, kom daar nog strominge by. Kerkeenheid kan slegs slaag as die strominge so met mekaar kan omgaan en gesprek voer dat daar sinergie kom. Dit kan slegs gebeur as die strominge goed verstaan word.

Die spanninge lei daartoe dat daar in 2005 klagtes oor leerdwalinge teen drie dosente van die Teologiese Fakulteit aan die Universiteit van Pretoria gelê is. Al drie is in 2006 deur hulle ringe onskuldig bevind, maar die spanning is nie ontlont nie. Die spanning vind waarskynlik sy brandpunt daarin dat Julian Müller, NG Professor in Praktiese Teologie, by verskeie geleenthede gekonfronteer is met die vraag: "Glo jy in die liggaamlike (of: 
histories-fisiese) opstanding van Jesus Christus?" - en hy geweier het om eenvoudig ja te antwoord. Later skryf hy: "En hoe meer ek daaroor dink en skryf, hoe minder kan ek op daardie vraag net eenvoudig 'Ja' antwoord” (Müller 2006:9).

Hierdie kritiek en die verweer word in die artikel as "die stryd" aangedui.

Die stryd bring onderliggende verskille in die geledere van die kerk na vore en bied daarom ' $n$ geleentheid om beter begrip te kry van wat aan die gang is in die kerk en die teologie. Die doel van hierdie artikel is om een van die strominge, soos verwoord deur Müller, te begryp en sodoende beter insig te kry in die posisie van die teologiese fakulteit in ons Suider-Afrikaanse konteks - soos wat dit is en soos wat dit kan wees.

Ek probeer begrip van die bepaalde teologiese stroming in die NG Kerk te kry deur gesprek te voer met Müller oor sy siening van die opstanding van Jesus, soos verwoord in sy boek Opstanding (2006). Ons het reeds verskeie persoonlike gesprekke hieroor gevoer, en gaan steeds daarmee voort. Ons ervaar dit albei as positief en verrykend, alhoewel dit nie altyd ' $\mathrm{n}$ maklike gesprek is nie. Ons wil graag die gesprek op ' $n$ openbare vlak voortsit. Ek publiseer daarom hierdie artikel met sy instemming, hoewel hy nie noodwendig met alles saamstem nie.

In die teologie is verskil van mening ' $n$ geleentheid vir gesprek, wat vir die funksionering van die teologie noodsaaklik is. ' $n$ Voorwaarde vir " $n$ goeie gesprek is dat beide partye moet ervaar dat hulle goed gehoor en billik weergegee is. Müller beweer meermale dat sy kritici sy standpunt so verkeerd formuleer, dat hy onbillik en selfs kwaadwillig aangeval word. Sy kritici mag dalk voel dat dieselfde met hulle gedoen word.

Ons hoop om met ons gesprek 'n paar voordele te bereik: ons mag die dinge waaroor ons wel saamstem beter formuleer en dalk ontdek dat ons meer saamstem as wat ons gedink het; ons mag ons verskille duideliker identifiseer en daarmee die algemene debat help suiwer van destruktiewe misverstande; albei van ons mag groei in ons eie verstaan van die Bybel en die teologie - ons kan, met ander woorde, self in die debat verander en oortuig word.

Deur die gesprek so te voer, word probeer om aan beide die eenheid van die kerk en die waarheid van die Bybelboodskap vas te 
hou. Eenheid moet ruimte maak vir verskeidenheid, soos wat daar in die Bybel ruimte is vir verskeidenheid en selfs, vir ons begrip, teenstrydige waarhede wat nogtans steeds as waarhede bely word. Aan die ander kant is daardie ruimte nie onbeperk nie en word sekere standpunte duidelik afgewys in die Bybel.

Daar word aan die eenheid vasgehou deur eers te probeer bepaal watter strominge en verskille daar is. Dan eers kan besluit word of ons nog dieselfde waarheid of versoenbare waarhede bely of nie, en hoe om dit te hanteer. Die vraag na die waarheid kan - en moet - dan beantwoord word.

Robuuste teologiese gesprek kan goed wees vir die kerk. Dit is egter "n vraag of oop gesprek, soos wat NP van Wyk Louw dit in 1955 beskryf, moontlik is in ' $n$ teologie met " $n$ belydenisgrondslag. Louw het in Holland terugverlang na die oop gesprekke in SuidAfrika, "...gesprekke waarin geen standpunt te 'gewaagd' is nie, waar jy alle moontlike vorme van die lewe - tot die vreemdstes toe van alle kante kon benader..." (Louw 1986:3). Die teologiese gesprek binne die kerk veronderstel egter die geloof en die belydenis as vertrekpunt, wat sekere standpunte by voorbaat uitsluit. Welker (2001:319, 330) sien die Bybelse geskrifte oor die opstanding as getuienisse, as kanoniese gedagtenisse wat ' $n$ sekere boodskap oordra.

As dit sou gevind word dat die teologiese strominge in die kerk onversoenbaar is, sal die tweede deel van Louw se beskrywing van die oop gesprek hopelik tog nog geld: “....en waar die gesprek nooit tot belediging, twis of woede sou ontaard nie." Maar hierdie ideaal is moeilik bereikbaar waar mense voel dat hulle diepste oortuigings bevraagteken word.

\section{DIE POSISIONERING VAN DIE STRYD IN DIE HUIDIGE TEOLOGIE}

Die artikel word geskryf vanuit die konteks van die studie van die Sendingwetenskap in Suider-Afrika. Dit is deel van ' $n$ gesprek tussen twee Afrikaanse lede van twee departemente, Praktiese Teologie en Sendingwetenskap. In die opsig verskil dit van, byvoorbeeld, ' $n$ gesprek oor die opstanding wat gevoer word tussen teoloë en natuurwetenskaplikes in Europa en die VSA. So 'n gesprek is te vinde in die bundel Ressurection. Theological and Scientific Assessments (Peters e a, 2002) - hoewel daar interessante raakpunte is. 
In die boek Opstanding beskryf Müller sy standpunt meermale as postmodern. Dit is " $\mathrm{n}$ belangrike leidraad in ons poging om die kritiek op hom, en sy verweer daarteen, te posisioneer in die groter teologie debat - en om die teologiese fakulteit te posisioneer in ons Suider-Afrikaanse konteks. Tog is dit nie so ' $n$ maklike leidraad om te volg nie.

Die term kom ook voor in die debat tussen die teologie en die natuurwetenskap, in die bundel wat hierbo genoem is. Daar word dit as volg beskryf: sommige teoloë, die objektiviste, aanvaar die geldigheid van die natuurwetenskaplike denke en redeneer dat die dinge waarin die kerk glo, byvoorbeeld die opstanding van Jesus, op een of ander manier objektief, natuurwetenskaplik, waar is. Die vraag aan Müller, of hy die histories-fisieke opstanding bely, klink na so ' $n$ objektivistiese vraag. Dit lyk ook of dit is waarteen hy beswaar maak. Die subjektiviste aanvaar die natuurwetenskaplike benadering eweneens, maar beweer dat die opstanding in die gemoed van die gelowiges plaasvind en daarom nie bots met die natuurwetenskaplike denke nie. Dit wat beweer word dat dit plaasgevind het in die geskiedenis vind neerslag in die gemoed en bestaan van sy volgelinge. Müller se antwoord op die vraag klink dikwels na so " $n$ subjektivistiese antwoord. Die interessante is dat, volgens Peters, die subjektivisme berus op 'n modernistiese skeiding van objek en subjek, wat in " $n$ postmoderne tyd onaanvaarbaar geword het, "...as modernity gives way to postmodernity". Die postmoderne denke aanvaar "...human subjectivity is deeply embedded in nature's history, in the history of all of nature from the Big Bang to the human present.... Whether Christian theologians like it or not, contemporary science forces us to ask questions such as: Did Jesus really rise from the dead?" (Peters 2002:xi, xii).

Daarmee klink dit of die postmoderne denke ons weer terugbring by die vraag waarmee Müller gekonfronteer is, " $n$ vraag waarop hy vanuit sy postmoderne raamwerk kritiek het. Die posisies van die partye in die stryd is nie meteens duidelik nie en daar moet fyner onderskei word. Ons kom weer hierop terug.

Die term postmodern word dikwels gebruik om die Afrikaanse leefwêreld te beskryf. " $n$ Goeie voorbeeld van die wyse waarop dit dikwels verstaan word, ook deur predikante en selfs teoloë, kan gevind word in ' $\mathrm{n}$ artikel, Drie strominge bedreig kerkeenheid oral (Rapport Perspektief, 2 Julie 2006:2). Daarin analiseer die joernalis 
Piet Muller die strominge in die Anglikaanse Kerk dwarsoor die wêreld. Hy gebruik populere kategorië. Hy skryf dat daar spanninge in daardie kerk is tussen drie strominge: die pre-moderne groep wat die Bybel letterlik verstaan, die moderne groep wat die kern van die Christelike leerstellings aanvaar, maar nie alles in die Bybel letterlik opneem nie, en die postmoderne groep wat "die letterlike verstaan van Jesus se maagdelike geboorte, sy opstanding en hemelvaart verwerp en ook nie glo dat die Chistendom die enigste weg tot saligheid is nie". Hy beweer dat die "konserwatiewe" stemme veral in Afrika en Asië sterk is, en eindig as volg: "Dit laat ' $n$ mens wonder oor die toekoms van die kerk wat tot stand sal kom uit die eenwording van die NG Kerkfamilie. Watter teologie sal uiteindelik in daardie kerk seëvier?"

Dit is nog ' $n$ oogpunt van waaruit die stryd bestudeer kan word: is die teoloog Julian Müller se postmodernisme tuis te bring in die meer populêre sienings van postmodernisme soos wat die joernalis Piet Muller hier bied?

Ons moet die gesprek, laastens, probeer posisioneer in die konteks daarvan dat ons ' $n$ fakulteit in Afrika is. Hoe relevant is ons kenteoretiese debatte in Afrika? Andrew Kirk, ' $n$ teoloog wat ' $n$ leeftyd aan teologiese opleiding in Suid-Amerika en Engeland gewy het, het ' $n$ fundamentele verskil in die uitgangspunte van die teologië in die Noorde en die Suide waargeneem. In die Noorde word die teologie se geldigheid getoets aan die vraag: voldoen dit aan die vereistes van die wetenskap? In die Suide, waar die teologie van bevryding die paradigma bepaal, is die fokus op "its ability to inspire people to be agents and embodiments of the life of God's new creation in Jesus Christ" (Kirk 1997:7). Dieselfde geld sekerlik in ons konteks. Wat beteken ons, die kerk en die teologie, en ons teologiese stryd vir armoede, onderdrukking, konflik en siektes in Afrika?

\section{DIE STRYDPUNT}

In hierdie artikel gaan dit oor die strydpunt dat Müller weier om eenvoudig "ja!" te antwoord op die vraag: "Glo jy in die liggaamlike (of: histories-fisiese) opstanding van Christus?"

Die vraag is of hy daarmee, in Piet Muller se woorde, “...die letterlike verstaan van Jesus se...opstanding en hemelvaart verwerp" en of hy slegs " $n$ bepaalde denkwyse verwerp. Kan hy, met ander woorde, op die vraag eenvoudig "Nee" antwoord? Kan hy op "n nie- 
eenvoudige wyse "Ja" antwoord? Hoe sou hy reageer op die vraag wat Peters as postmodern beskou: "Did Jesus really rise from the dead?" Wat beteken die vraag en die antwoord vir die posisie van die kerk en die teologie in die Suider-Afrikaanse konteks?

Müller het die boek Opstanding (2006) geskryf om te verduidelik waarom hy so reageer het. In hierdie artikel gaan ek veral in gesprek met die standpunte in hierdie boek. Ek bied my verstaan van die strominge aan deur ' $n$ paar stellings te maak en te beredeneer.

\section{BEREDENERING}

Eerste stelling: Die verdelingslyne loop dieper as kerkverband, dieper as die verdeling tussen wetenskap en geloof of Fakulteit en Kerk, en dieper as verskille tussen teologiese vakdissiplines

Die stelling word baseer op ' $\mathrm{n}$ artikel, ' $n$ Hervormde tradisie as heelmiddel, wat die Bybelwetenskaplike Jimmy Loader meer as tien jaar gelede publiseer het (1996:566-588). Daarin kritiseer hy vir Andries van Aarde, ook ' $n$ Bybelwetenskaplike, oor Van Aarde se reaksie op die vraag of hy glo in die opstanding van Jesus Christus dieselfde vraag wat nou weer pertinent ter sprake gekom het in die NG Kerk. Dit is interessant tot watter mate Müller se antwoorde ooreenstem met die antwoorde wat Van Aarde ' $n$ aantal jare gelede reeds gegee het. Beide het geweier om met " $n$ eenvoudige ja te antwoord. Dit lyk asof daardie debat in die Hervormde Kerk herhaal is in die NG Kerk. Op die oog af hoort Müller en Van Aarde bymekaar, en hulle kritici by Loader - maar dit is dalk nie so eenvoudig nie.

In Loader (1996:575) se beskrywing van die debat in die Hervormde Kerk klink dit asof Loader se kritiek op Van Aarde net so op Müller van toepassing kan wees:

"Op die vraag hoe hy die opstanding sien, antwoord hy (Van Aarde) dat hy dit 'soos die Kerk en saam met die Kerk' bely. Maar wanneer hy gevra word om dit te begrond, kwalifiseer hy sy belydenis. Hy kritiseer die 'moderne mens' wat soek na 'meer as die Woord' en die 'empiriese wetenskapsbeskouing' wat alleen glo wat bewys kan word en dit koppel aan die 'historisiteit van ' $n$ saak'. Volgens hom het sulke empiriste eenmaal vir Rudolf Bultmann gevra of Jesus opgestaan het, waarop 
sy antwoord was: 'Ja - in die kerugma'. Hierby voeg professor Van Aarde: 'Ons kan eintlik geen ander antwoord gee as om te sê dat wat ons van die opstanding weet en bely, deur die Woord aan ons verkondig word nie. By daardie antwoord staan ek ook"'.

Müller klink, tien jaar later, baie dieselfde as Van Aarde. Van Aarde het geantwoord dat hy die opstanding bely "soos die Kerk en saam met die Kerk". Müller (2006:8) het 'n soortgelyke antwoord gegee: "...dat ek daardie Sondagoggend nog in die kerk was en saam met die gemeente die Twaalf Artikels bely het, wat onder andere sê dat ek glo in Christus "wat op die derde dag weer opgestaan het'".

Soos Van Aarde kwalifiseer Müller die belydenis as hy vir ' $n$ fisieke en historiese begronding gevra word (daaroor later meer). Van Aarde het verwys na empiriste, Müller verwys na die kwessie van bewyse. Van Aarde sê dat ons glo op grond van die Woord wat verkondig word, Müller sê ons glo op grond van die verhaal wat aan ons vertel word: "Ons glo nie op grond van bewyse nie, maar op grond van die verhaal wat aan ons vertel word en op ons ' $n$ appél maak".

Müller verwys na ' $n$ brief van Gerrit Brand in Beeld, dat die maagdelike geboorte van Jesus nie histories of wetenskaplik as waar of vals bewys kan word nie. Die wat bewyse soek daarvoor moet ook maar uiteindelik, soos ons almal en soos die dissipels wat voor Jesus gestaan het, antwoord op die vraag wie Jesus is. "Of jy nou 'metafories' glo en of jy 'letterlik glo', uiteindelik is die vraag of jy saam met Petrus bely dat Jesus die Christus is, die Een wat God se hart vir ons oopmaak waardeur ons gered word" (Müller 2006:6769).

Soos Müller dit hier formuleer gaan die stryd nie oor die vraag of " $n$ mens die opstanding bely of glo of nie, maar of jy dit "metafories glo" en of jy dit "letterlik glo". Dit blyk hieruit dat die belydenis van die opstanding vir verskillende mense verskillende dinge kan beteken, al word dieselfde woorde in die kerk bely.

Dit is soms baie moeilik om te verstaan of ' $n$ uitspraak beteken dat iemand iets letterlik of metafories glo. Byvoorbeeld, by geleentheid verduidelik Van Aarde sy siening van die kerk se belydenis, waarmee hy instem, as volg: "Hierdie Jesus is gekruisig maar vir die kerk is Hy die lewe, omdat die kerk sy opstanding uit 
die dode glo en (Hy) vir die kerk die Christus, die Here, die manifestasie van God is" (aangehaal deur Loader, 1996:574).

Dit klink asof Van Aarde die opstanding letterlik bely. Loader (1996:574-577) analiseer Van Aarde se antwoord egter en vind dit ontoereikend. Hy konkludeer dat Van Aarde die opstanding van Jesus skynbaar hier bely, maar dat daar in werklikheid proposisies gemaak word oor die geloof van die kerk en nie oor die opstanding nie. Hy sê dat Van Aarde eenvoudig kon gesê het: "Jesus Christus het uit die dode opgestaan", maar dat hy die uitspraak vermy en dan in effek ander proposisies maak, byvoorbeeld dat die kerk sy opstanding glo.

Müller se kritici is eweneens nie oortuig deur sy verduidelikings van sy belydenis van die opstanding nie.

Loader se standpunt is verder dat Bultmann onder die druk van die empiriese wetenskap geswig het toe hy gesê het dat Jesus in die kerugma, in die boodskap wat deur die kerk verkondig word, opgestaan het. Dit kan immers empiries bewys word dat die kerk in die opstanding glo, maar nie dat die opstanding letterlik of histories plaasgevind het nie. Dit is - paradoksaal genoeg - "akkommodasie van die empiriese waarheidsbeskouing" deur iemand wat die modernisme verwerp (Loader 1996:575).

Al drie persone, Müller, Van Aarde en Loader, verwerp wel die empiriese waarheidsbeskouing, waarvolgens slegs dit wat bewys kan word, waar is. Loader lei daaruit af dat die gebrek aan empiriese bewyse ons nie keer om die opstanding ongekwalifiseerd te bely nie. Hy beskou dit as inkonsekwent dat Van Aarde, uit vrees vir ortodoksie en empirisme, terugdeins van ' $n$ ongekwalifiseerde belydenis van die opstanding omdat dit nie empiries bewys kan word nie. Soos Bultmann akkommodeer Van Aarde die empiriese waarheidsbeskouïng deur die proposisie van Jesus se opstanding uit die dode te vervang met die proposisie van die opstanding in die kerugma en die belydenis van die kerk (Loader 1996:575, 576). In Peters se terminologie (sien hierbo) beteken Loader se kritiek dat Van Aarde subjektivisties is en dat dit nog steeds modernisties is.

Loader wys benaderings soos die ortodoksie en Bultmann se kerugmatiese benadering af en sê dat die kerk gebou is daarop dat ons deur God, die groot Subjek en die enigste Waarheid, gegrepe is. Dit lei tot ' $n$ intersubjektiewe verhouding tussen God en ons. Op 
grond van hierdie gegrepenheid deur God bely ons, preek ons, en formuleer ons proposisies.

Ek stem met Loader saam dat ons die liggaamlike en historiese opstanding eenvoudig kan bely, juis omdat ek die moderne denkwyse, met al die positiewe daarvan, as ontoereikend beskou om in alle gevalle oor die waarheid te kan beslis. Dit is nie onwetenskaplik om te erken dat ons rede soms ontereikend is nie. Dit is so dat die opstanding en die Bybel nie pas in ' $n$ modernistiese siening nie. Maar die probleem word nie opgelos deur die opstanding subjektivisties te verstaan nie. Die teologiese wetenskap word steeds gekonfroteer met die vraag na die historiese en liggaamlike opstanding, en moet daarop antwoord.

Van Aarde het hom op Bultmann beroep. Of Müller hom hierin volg, weet ek nie. Die debat in die NG Kerk toon wel merkwaardige ooreenkomste met hierdie debat wat in die Hervormde Kerk plaasgevind het, al is dit nie in alle opsigte presies dieselfde nie.

Gevolgtrekking by die eerste stelling: Die ooreenkomste tussen die stryd in die Hervormde Kerk, soos beskryf in Loader se artikel, en die onlangse stryd in die NG Kerk illustreer duidelik dat die verdelingslyn(e) nie bloot loop tussen die Bybelwetenskappe en die ander teologiese dissiplines, of tussen teologie (wetenskap) en geloof, of tussen die Fakulteit en die Kerk, of tussen die NG en Hervormde kerke, of tussen kulture nie. Dit is " $n$ stryd wat aandui dat daar grondliggende verskuiwings in ons denkwyse aan die gang is wat ons self nog nie goed begryp nie.

Tweede stelling: Müller verset hom met al sy krag teen strominge wat hy voel uitgedien is en agtergelaat moet word

Müller sê wel sy boek is "nie bedoel as " $n$ polemiese of strydgeskrif nie", want deur die genade is hy verby woede en bors skoonmaak ( $\mathrm{p}$ 7), maar dit is nietemin ' $\mathrm{n}$ boek waarin hy protes aanteken "teen ' $\mathrm{n}$ teologiese stroming wat my erg bekommer. Ek protesteer teen ' $\mathrm{n}$ bepaalde opvatting van die opstanding van Christus...ek het behoefte om met my hele hart daarteen te protesteer, omdat die vraag en die manier waarop die vraag geformuleer en gevra is, " $n$ teologie oor die opstanding verteenwoordig wat ek nooit kan onderskryf nie" (pp7-9). Elders ( $p$ 75) skryf hy: "....met my volle verstand en met al my kragte bied ek ook weerstand....". 
Die woorde hele, volle, al, nooit en niks dui daarop dat hy dink aan twee opvattings of twee teologieë wat onversoenbaar met mekaar is. Soos hy self sê, sy boek moet verstaan word teen die dekor van stryd, van aanklagte en beskuldigings. Hy moet ernstig geneem word: die verskille kan nie met oppervlakkige formulerings versoen word nie

Müller se siening van die verbygaande of uitgediende fase kan uit verskillende aanhalings afgelei word. Hy gee nie 'n enkelvoudige siening daarvan nie.

In die Woord vooraf gaan dit veral oor die "terugval na fundamentalisme...soos in die res van die Westerse wêreld". Müller verwys na die "groeiende evangeliese fundamentalisme in die geledere van die Afrikaanse kerke" (p 10). Op bladsy 11 is ' $n$ verwysing na ' $n$ vloedgolf van fundamentalisme wat ons sal vernietig en wat gekeer moet word. En op bladsy 75 noem hy dit "die evangeliese fundamentalisme".

In hoofstuk 1 gaan dit oor die wat hom aankla. Hy laat geen twyfel daaroor dat ons hier " $n$ ernstige stryd het nie, want hy begin by die groot teenstander, Satan, wat die rol van aanklaer speel in die boek Job. Dan trek hy die lyn deur na Job se vriende, en dan verder na die hedendaagse populêre teologie met sy "eenvoudige, suksesgeörienteerde slagspreuk-benadering" ( $p$ 14) en sy "aanspraak op wonderwerke".

Op bladsy 42 beskryf hy die konflik in terme van modernisme (dogma) teenoor postmodernisme (poësie en verhale): "Ons ly nog onder die Verligting. Die taal van die modernisme was en is die taal van die Verligting .... Dit is " $n$ taal wat streef na letterlikheid en korrektheid. En hoe meer letterlik en korrek, hoe leër het dit geword."

Op bladsy 86 reageer hy op ' $\mathrm{n}$ verbygegane politieke ideologie en wêreldbeeld: "Die ervaring van vervreemding by Christene in ons konteks is ten nouste verbind met die Afrikaner-identiteit wat in duie gestort het omdat dit nóú geassosieer is met die ideologie van apartheid....Binne hierdie situasie bly ' $\mathrm{n}$ groot deel van die Afrikaner hoofstroomkerke steeds verkleef aan die dualistiese teologiese wêreldbeeld".

Op bladsy 100 verwys hy na “...'n bolangse charismatiese wondergeloof wat mense vir die oomblik fassineer, óf...'n 
fundamentalisties-moralistiese prediking waar die ou inhoude op ' $n$ nog ouer styl verkondig word".

Op bladsy 121 is " $n$ opmerking: “.... 'n kerk wat mag put uit religieuse burokrasie...".

Bogenoemde is alles deel van die fase wat opgeruim moet word.

Een van die ander twee dosente wat aangekla is, Jurie le Roux, Professor in $\mathrm{Ou}$ Testament, gee ' $\mathrm{n}$ duidelike beskrywing van hoe hy die teologie van sy aanklaers verstaan. In die notas wat Le Roux uitgedeel het by ' $n$ gesprek tussen dosente in Junie 2006, met die opskrif Die toekoms van die teologie aan die Universiteit van Pretoria, skryf Le Roux onder die subopskrif Die soort teologie waarmee ons gekonfronteer word as volg:

"Vertrek vanaf 'n vaste punt ('n histories-letterlike), formuleer kernwaarhede (die histories-letterlike, liggaamlike opstanding); kenmerk van die waarhede is die empiriese of positiwistiese karakter (die letterlike, presiese, feitelike gebeure en foutlose, vanselfsprekende teks); die gebruik van magsmiddele (soos die Skrif en belydenisskrifte); die histories-letterlike verstaan van die Skrif (vat alles soos wat dit daar staan letterlik); geen oog vir die histories-kritiese Bybelwetenskap nie; dit gaan om absolute waarhede wat net sekeres ken en waartoe ander gedwing moet word; alles word ' $n$ magspel; kritiese refleksie is onmoontlik; alle word in proposisies uitgedruk."

Müller (2006:115) ervaar dit blykbaar dieselfde. Hy distansieer hom van diegene wat presies die regte woorde en formulerings van hom eis: "Wat ek probeer doen, het niks te doen met die pogings van die ortodoksie en fundamentalisme om met korrekte formulerings die 'waarheid' te probeer beskerm nie."

Die mense aan wie hierdie soort denke toegeskryf word, sal eweneens moet aandui of hulle met die beskrywing van hulle denke saamstem. Loader het hom duidelik distansieer van die modernisme, konfessionalisme en ortodoksie, vir wie die waarheid primêr in proposisies te vinde is. Le Roux se kritiek is waarskynlik nie op hom van toepassing nie. Die sterk negatiewe beskrywing van mekaar, aan beide kante, is ' $\mathrm{n}$ aanduiding dat die polarisasie ernstig is. 
In sy boek Na het postmodernisme gee C A van Peursen (1995) ' $n$ oorsig oor die filosofie van die Weste. Hy beweer dat die groot fases telkens eindig in skeptisisme, waardeur die vaste sekerhede van die verbygaande fase bevraagteken en opgeruim word (Van Peursen 1995:138). Dit berei die weg voor vir ' $n$ nuwe fase met nuwe paradigmas en oortuigings - dikwels die herontdekking van die ou waarhede in ' $n$ nuwe idioom. Die postmodernisme is so " $n$ tussenfase. Dit diskrediteer die modernisme en baan die weg vir die herontdekking van ou waarhede in ' $n$ nuwe idioom. Dit beteken dat die fase ná die postmodernisme vir die toekoms belangrik is.

In Suid-Afrika kan ons ' $n$ eie gestalte van die proses verwag, omdat die kulturele veranderinge saamloop met ingrypende sosiopolitieke veranderinge.

Gevolgtrekking by die tweede stelling: Müller se boek is ' $\mathrm{n}$ poging om die oorblyfsels van ' $n$ verbygegane fase op te ruim. Die huidige spanninge is nie net teologies van aard nie, maar het iets te doen met die kulturele en sosio-politieke veranderinge van ons tyd en van ons plek. In die soeke na ' $n$ sinvolle rol in die nuwe konteks kan die verlede ' $n$ hindernis wees. Afskeid van dit wat nie meer sinvol is nie is belangrik, al is dit nie voldoende om die nuwe te verstaan nie.

Derde stelling: Müller voer die motiewe en gesindhede van sy aanklaers aan as die hoofrede waarom hy weier om op hulle vrae te antwoord

As ek dit reg verstaan, weier Müller om die vraag te antwoord of Jesus histories-fisiek opgestaan het omdat hy die motiewe en gesindhede van die aanklaers onaanvaarbaar vind. Net ' $n$ enkele keer, sover ek kon sien, word die vraag self ook as onaanvaarbaar aangedui: “....ek het behoefte om met my hele hart daarteen te protesteer, omdat die vraag en die manier waarop die vraag geformuleer en gevra is, ' $n$ teologie oor die opstanding verteenwoordig wat ek nooit kan onderskryf nie" (p 9). Maar gewoonlik gaan dit oor die waargenome gesindheid agter die vraag.

Die eerste keer dat die vraag gevra is, was dit vir hom soos " " $n$ pistool teen die kop.... in " $n$ konfronterende en uitdagende gesindheid...". Die doel was "om my uit te sluit..." (p 9, 10).

Job se aanklaers en die hedendaagse populêre teologie is van dieselfde aard. "Hulle teologie is selfregverdigend en veroordelend" 
(p 16), “ 'n teologie van arrogante sekerheid, 'n teologie wat presies weet hoe dinge inmekaarsteek" (p 17).

Van die aanklaers sê hy: “...dit gaan vir hulle glad nie oor die opstanding nie. Die opstanding van Jesus word misbruik om ander dinge te sê en ander dinge te bereik" (p 37). Dit is "n sterk stelling.

Die neiging om na korrekte formulerings te soek lê in die verlengde van dogma wat wil beheer uitoefen: “...die ongesonde dogma van die ortodoksie (wat) probeer vasmaak en voorskryf met min of geen ruimte vir ' $\mathrm{n}$ eie individuele verstaan en belewenis... Modernisties geformuleerde begrippe oor die opstanding, soos 'histories-fisiek' of 'histories-letterlik' wil nie ruimte laat vir meervoudigheid van God se rykdom en genade nie. Dit wil met letterknegtery beheer uitoefen oor ander se geloof" (pp 41, 42, 43).

Bladsy 118: "Wat ' $n$ vergryp teen die opstanding self as die mense met hulle geleerde woorde probeer om die opstanding finaal vas te vang in geloofsformules!"

Bladsy 119: "Dit dra die skyn van besorgdheid oor die korrekte leer en daarom besorgdheid oor die regte geloof. In werklikheid is dit egter pogings om met bepaalde formulerings beheer uit te oefen en om die eie interpretasie te verhef tot die enigste. So word die fundamentalistiese ortodoksie "n nuwe wettisisme."

Paulus se uitspraak in 1 Korintiërs 15:17 word dan "byna 'n kerk-politieke slagspreuk waarmee veral konserwatiewe gelowiges tevrede gehou word....'n Formule waarmee die deksel op die pot gesit word en wat alles finaal afrond ....Dit staan teenoor die opstanding as begin, wat jou lewe moet begin verander ..." (Müller 2006:120).

Die besliste weiering om direk positief te antwoord op die vraag of hy die historiese en fisiese opstanding van Jesus aanvaar skep die indruk dat Müller die letterlike verstaan van die opstanding verwerp en dat Piet Muller se beskrywing van die postmoderne geloof volledig op hom van toepassing is. Dit is egter my indruk, soos verderaan sal blyk, dat hy nie eenvoudig kan Nee sê nie, net soos wat hy nie eenvoudig kan $J a$ sê nie. Hoe sal hy byvoorbeeld reageer indien dieselfde vraag met ' $n$ ander gesindheid en motief gevra sou word, of as hy die motiewe van die vraers buite rekening laat? 
Gevolgtrekking by die derde stelling: Gesprek is ' $\mathrm{n}$ manier om te probeer vashou aan beide die eenheid en die waarheid van die geloof. Eenheid, omdat ons mekaar nie laat los nie. Waarheid, omdat ons dit wat ons glo, nie laat los nie. Maar sonder wedersydse vertroue is konstruktiewe gesprek onmoontlik. Dit is belangrik dat daar partye na vore tree wat die vertrouensbreuke wat ontstaan het, kan oorbrug.

Vierde stelling: Die Sendingwetenskap het gewoonlik ' $n$ ander benadering tot hierdie vrae as die Pastorale Teologie

In die jongste tyd is die historiese aard van die eskatologie - en die Bybelse geloof as sulks - (her)ontdek. Bosch (1994:499) wys daarop dat die herontdekking van die eskatologie veral in sendinggeledere manifesteer het. Dit is nie verbasend nie, want van die begin af was daar ' $n$ besondere affiniteit tussen die sending en die verwagting dat die mensdom se toekoms fundamenteel verander het in Christus. Openbaring dui nie op die bekendmaak van die onbekende of verborge dinge of misteries, soos die Griekse denke dit verstaan het nie - dit dui op God se selfbekendmaking in sy dade in die geskiedenis.

Bultmann het ' $n$ nie-historiese teologie gehad. Dit is in 1953 in die Sendingwetenskap toegepas deur W Holsten in sy boek Bosch verwys daarna Das Kerygma und der Mensch (vgl Bosch: 502, 503). Hiervolgens bied sending aan mense die geleentheid tot "n nuwe self-verstaan in die lig van die kerugma (Bosch 1994:502, 503). Hierdie benadering kan dalk werk in " $n$ Pastorale Teologie wat tradisioneel gerig is op die individualistiese middelklas-lidmate van kerke in die Weste. In die Sendingwetenskap het Holsten se toepassing daarvan egter min waarde gehad en min inslag gevind. In nie-Westerse kommunale kulture is selfverstaan nie so belangrik nie - groepsverhoudinge is die brandende kwessie, om nie te praat van die stryd met groot en harde magte nie: politieke ideologieë, ekonomiese kragte, die stryd teen siektes en armoede, kulture, godsdienste, onrus en onstabiliteit.

In die eskatologie is die twee terme waarmee Müller probleme het, histories en fisiek, juis deurslaggewend. Die verskil tussen die eskatologiese denke in die Sendingwetenskap en Müller se denke kan aan die hand van drie sake verduidelik word: die sienings van die geskiedenis, van die eindtyd en van die fisieke werklikheid. Hierdie drie sake word nou kortliks bespreek. 
a) Die siening van ons verhouding met die geskiedenis

Waar Bultmann - en Müller - die metafore sterk beklemtoon, neig die Sendingwetenskaplikes en ander teoloë om die meer konkrete aspekte van die geskiedenis te beklemtoon, die vraag hoe ons kan vorder met die saaklike probleme van die wêreld: wat beteken die reeds en die nog nie van die koms van die Koninkryk van God vir die sekulere geskiedenis? (vgl Bosch 1994:508). Dit is ' $n$ klemverskil.

Toe die eskatologie herontdek is, is die koms van die Koninkryk as ' $n$ gebeure in die hart van die wêreldgeskiedenis verstaan: die Koninkryk het reeds begin kom in die wêreld terwyl die ou bedeling nog voortgaan. Die nuwe hemel en aarde werk vernuwend in op die hede. Die eskatologie, Moltmann se teologie van hoop en die gekruisigde God - dit alles was belangrik om die kerk te oortuig dat ons betrokke moet raak by die politiek en die ekonomie van die wêreld, by die harde werklikhede, die konkrete lyding van mense (sien ook Welker 2001:328). Die metafore, persepsies, kultuurpatrone, simbole, godsdienstige oortuigings, ensovoorts is belangrik omdat hulle in die gang van die werklikheid ' $n$ rol speel, nie maar net vir ' $n$ beter self-verstaan nie. God is besig met en gerig op die geskiedenis en dit maak die historiese opstanding belangrik.

Die eskatologie staan reëlreg teenoor die meganistiesdeterministiese wêreldbeeld van Newton. Die eskatologie verwag nuwe dinge in die toekoms. Die geskiedenis het ' $\mathrm{d}$ doel waarheen dit op pad is. Ons streef na daardie doel omdat ons hoop dat die toekoms nuut en anders kan wees. Die Verligting het die hoop tot niet gemaak omdat hulle alles verstaan het in terme van oorsaak en gevolg, wat ons gevangenes maak van die verlede: alles wat nou is, is gevolge van die verlede en nie gerig op " $n$ doel in die toekoms nie (Bosch 1994:499). Die eskatologiese denke stem op hierdie punt saam met Müller dat die modernisme uitgedien is. Bosch (1994:509) sien die eskatologie en die postmoderne paradigma van die sending as onlosmaaklik van mekaar - reeds sedert Tambaram, 1938. Die Sendingwetenskap het toe reeds begin dink in terme van " $n$ bepaalde soort postmodernisme.

Hierdie soort denke is nie idealisties nie en kan aansluiting vind by ' $n$ stelling wat die Rooms Katolieke teoloog Hans Küng mak oor Nietzsche se verset teen die idealistiese filosofie van sy 
tyd. Die idealisme het min klem gelê op die realiteite van God, medemens, en die dinge. Hulle het die ideale, wat gegrond is op die mens se eie subjek en verstand, hoog aangeslaan. Nietzsche het, in navolging van Jacobi, beswaar daarteen gemaak dat die waardes losgeraak het van die dinge self en van die lewe, en as selfstandige groothede funksioneer het. Daarom het Nietzsche die waardes en ideale van die mens - waarheid, wetenskap, filosofie, verstand, liefde, moraal, kultuur, godsdiens, asook die geloof in vooruitgang en die medelye met noodlydendes - as leeg en sinloos afgemaak en radikaal verwerp (Küng 1981:383, 431-432).

Hierdie kritiek kan ook gerig word aan 'n neiging in die kerk vandag om net te volstaan met simboliese handelinge wat selfstandig funsioneer, los van die harde werklikhede. 'n Dominee steek 'n kers aan vir Vigslyers, maar dit bly daarby en lei nie tot betrokkenheid by 'n werklike Vigslyer nie. Die simboliese handeling bly los van die werklike nood van mense. Die neiging kom voort uit ' $n$ soort postmodernisme wat neig om teen die simboliese of metaforiese werklikheid vas te kyk en dan die werklike lewe met mense se werklike nood mis te kyk. My vraag is of Müller se beklemtoning van metafore en simbole nie - onbedoeld - hiertoe bydra nie.

In Hoofstuk 3 gee Müller aandag aan die geskiedenis. Hy beskryf die verhouding tussen historiese en metaforiese betekenis as én-én: die simboliese en metaforiese interpretasies van die groot dade van God bou op die historisiteit van hierdie dade (p 31). Deur die storie (story) word die historie (history) ook myne (p 33). Hy haal " $n$ stelling van Bosch oor die eskatologie aan: "In the resurrection of Christ the forces of the future already stream into the present and transform it, even if everything that meets the eye appears to be unchanged" ( $\mathrm{p} 33$ ).

Müller sien die simbole en die historiese gebeure as aanvullend: die simboliese interpretasies wat aan die groot verhale van God geheg word "doen niks afbreek aan die historisiteit daarvan nie" ( $p$ 31). Die verhaal veronderstel die historiese gebeure, maar ons het net die verhaal. Die verhaal is ons enigste band met die gebeure.

Mettergaan, lyk dit my, begin die verhaal of simbool dan ' $n$ eie lewe lei en vervaag die verhouding met die gebeure self. Müller skryf deurgaans in nie-eskatologiese terme. Waar Bosch die kreatiewe spanning tussen metafoor en gebeure behou, gee Müller 
dit prys. Om een voorbeeld te noem: op bladsy 105 en verder beskryf hy die simbool vry van die geskiedenis, met verwysing na Dan Brown se Da Vinci Code, waarin die hoofkarakter sê: “Telling someone what a symbol 'meant' was like telling them how a song should make them feel - it was different for all people'...".

Müller sluit by hierdie stelling aan: "Dit is waar van simbole. Hulle laat hulle nie voorskryf nie. Hulle is glibberig en halsstarrig....Dit is die wonder van simbole. Daarom kan ' $n$ mens nie voorskryf wat die betekenisinhoud van die doopritueel vir iemand moet wees nie...die wonderwêreld van simbole, metafore en rituele."

Hierteenoor kan gevra word of die belydenisskrifte, waarna Müller graag verwys, nie juis opgestel is om aan dopelinge voor te skryf en hulle te onderrig in wat hulle moet glo nie. As die subjek hom of haar nie laat voorskryf hoe hulle die geloof moet verstaan nie, is dit die soort oop gesprek wat moeilik in die kerk tuiskom. Welker (2001:330) onderskei die kanoniese gedagtenis van ' $n$ kommunikatiewe gedagtenis wat vloeibaar bly.

Waar Müller die krag van simbole beklemtoon, praat ' $\mathrm{n}$ sendeling soos Hendrik Kraemer, die hooffiguur by Tambaram in 1938, van die krag van die werklikheid. Kraemer waarsku dat die werklikheid hom nie in ons persepsies, ideale en gedagtes laat inpas nie: die "onwedergebore praktyk" skik hom eenvoudig nie volgens ons voorskrifte nie. Hy praat van "harde feiten, die zulk een duchtig woord meespreken om menschen te dwingen wegen te bewandelen...de dwang der geweldige feiten" wat vele dwing tot erkenning: "de donder der feiten heeft hier gesproken" (Kraemer 1932:131-134). "De geloof overwint de wereld door haar te erkennen, niet door haar te negeren" (:163, vgl 174, 178).

Kraemer praat in sulke sterk terme omdat hy dit het oor die groot gebeure in Indië. Hy besin nie rustig in 'n middelklas-konteks nie. Dieselfde sterk terme kan gebruik word ten opsigte van huidige prosesse in Afrika. Ons simbole en persepsies - byvoorbeeld dat ons ' $n$ liberale demokrasie is omdat ons so " $n$ grondwet het, of dat ons in ' $\mathrm{n}$ postmoderne land woon - kan nie stand hou teen die donderslae van groter magte en prosesse in Afrika nie. Die ontwikkelingsplanne wat die Weste aanbied en wat op ons persepsies gebaseer is, wil nie werk in Afrika nie. In ons denke en simbole moet ons met die werklikheid besig wees: ons moet dit goed ken en respekteer en daarop antwoord. As ons in 'n wêreld leef van simbole wat los is van 
die dissipline van die geskiedenis en van die werklikheid, is ons eerder met die Griekse denke as met die Bybelse boodskap besig.

Gevolgtrekking oor Müller se verhouding met die geskiedenis: Dit is my indruk dat Müller in sy narratiewe benadering veral werk met metafore en simbole, maar die eskatologie, die spanning tussen die reeds en die nog nie in die geskiedenis, prysgee. Die opstanding word beskryf soos dit ervaar word in die leefwêreld van die gelowige, dit word nie beskryf as die dryfkrag in die hart van die Suid-Afrikaanse geskiedenis, as ons enigste hoop en troos in die stryd met groot en harde magte nie: politieke ideologieë, ekonomiese kragte, die stryd teen siektes en armoede, kulture, godsdienste, onrus en onstabiliteit, die bedreiging van die ekologie. Meer daaroor in sy bespreking van die eidtyd.

\section{b) Die eindtyd}

Vroeër is nogal gedink die kerk het nie 'n oog vir die fisieke nood van mense nie omdat ons die evangelie onder die invloed van die Griekse dualisme te geestelik verstaan het. Dat ons net die redding van die siel gesien het. Dat ons die pie in the sky when you die verkondig het, maar niks gedoen het aan mense se ellende hier en nou nie. Sendingwetenskaplikes soos David Bosch het baie aandag gegee aan die saambring van die evangeliese en ekumeniese rigtings, die verlossing vir die ewige lewe sowel as die vernuwing van die samelewing. Hy sluit aan by die inkarnasie, die Woord wat vlees word, die opstanding van die vlees, die eenheid van liggaam en siel, wat ons dring om betrokke te raak by sowel die konkrete nood van mense en die verlossing vir die ewige lewe.

Moltmann het daarop gewys dat die Christelike hoop die hier en nou oopbreek na die toekoms toe: omdat ons die volkome oorwinning oor die dood en die bose aan die einde in die geloof verwag, en daardie oorwinning reeds met die opstanding van Jesus begin het, kan ons nie aanvaar dat die huidige bedeling onherroeplik deur die magte van die dood beetgeneem is nie. Ons sê die stryd met hulle aan. Die inkarnasie en die hemelvaart - dit is, dat Jesus by God is en sy heerskappy vestig oor alle magte - maak ons aktief betrokke by mense se daaglikse nood.

Dit is interessant dat Müller met ' $n$ ander roete by die mens in nood uitkom. Op bladsye 125 en 126 skryf hy: "Die hemelvaartboodskap sê: Jesus het in die wolk verdwyn, maar aan die ander kant uitgekom, verbloem as die arme, die hongerige of wie ook al wat ons 
paaie kruis....Hy woon nie 'in die hemel' nie. Hy woon hier.....nou aanbid ons die opgestane Here. Nou loop Hy, slaap Hy, werk Hy, speel Hy, voel Hy, vat Hy, is Hy menslik en tasbaar tussen ons en by ons, nooit sonder ons nie." Die hemelvaart word hier in die lig van Matteus 25 verstaan: in soverre julle dit aan een van die geringstes gedoen het, het julle dit aan My gedoen. Jesus is na die hemelvaart te vinde by die geringstes.

Die opgestane Jesus ontmoet ons in die mens in nood. Ons vind Hom "...tussen die armes en die vroue; die sondaars en prostitute; die hervormers en die rewolusionêre, die gevangenes en die kinders" (p 103).

Dit word in die persoonlike, nie-eskatologiese taal van die subjektiewe geloofservaring beskryf, byvoorbeeld op bladsy: die Emmausgangers se ervaring word ons ervaring: "Dan ontdek jy God in die laggie van ' $n$ kind, in die oë van die arme, in die opregtheid van ' $n$ sondaar. En dan kyk jy terug op " $n$ doodgewone ervaring en jy sê vir jouself: Het my hart nie warm geword toe dit en dat gebeur het nie?"

Müller beskryf Jesus se nabyheid aan ons treffend. Hy is nou, hier teenwoordig by ons, deur die mens in nood en op ander maniere. Maar dit lyk asof hy die spanning. tussen sy teenwoordigheid by die swakkes en sy voortgesette heerskappy oor alles, sy teenwoordigheid by God in die hemel, prysgee. Jesus is by ons, maar ons kan tog nie sê Hy is nooit sonder ons nie! Dis juis andersom: Hy doen oneindig veel sonder ons. Ons bely immers dat Hy die Skepper en die Onderhouer van hemel en aarde is. Maar ons kan nooit iets doen sonder Hom nie.

Die grootsheid van die gebeure kom baie beter na vore as ons beide die teenwoordigheid van Jesus op aarde en in die hemel beklemtoon. Dit gebeur in die sg "extra calvinisticum" van die Heidelbergse Kategismus, Sondag 18, vraag 48, of soos Calvyn - dit volgens die Hollandse vertaling beskryf: "Want de Zoon Gods is op wonderbare wijze uit de hemel neergedaald, zonder dat Hij de hemel verliet..." (soos aangehaal deur G C van Niftrik in sy boek De bestaan van God, 1971:124). Op die manier, sê Van Niftrik (1971: 126) word duidelik gemaak dat die goddelike die menslike dra, omvat, deurtrek, maar tegelykertyd die menslike oneindig transendeer. Omdat God heeltemal God bly, kan die mens homself gun om heeltemal mens te bly. "De actualiteit van deze dogmatische 
beschouwingen zal toch hopelijk duidelijk zijn. Wij constateerden in de huidige theologie minstens de tendens God op te sluiten in de naaste...."

Volg Müller ook die tendens na om God op te sluit in die naaste? Aan die een kant lyk dit nie so nie: Hy sê op bladsye 102 en 103: Jesus verskyn en verdwyn op die vreemdste plekke en maniere. Hy het telkens weer uit die magsgrepe van mense uitgestap. Op bladsy 60 skryf hy: "Na sy opstanding is Jesus soos ' $\mathrm{n}$ bal in Platland. Hy doen die vreemdste dinge en wil nie lekker in die vakkies inpas nie."

Hy sê dit mooi op bladsy 123: "Hy kan nie vasgevang word in 'n klompie verhale en leerstellings in "n boek nie...". Hy transendeer immers ons stories en ons simbole (waarvan Müller hou) net soveel as ons dogma's (waarvan hy nie veel hou nie).

Aan die ander kant maak Müller stellings wat lyk asof Jesus wel opgesluit is in ons naaste, veral die naaste in nood, byvoorbeeld die stelling dat Hy nooit sonder ons is nie, en: "As ons vir Jesus nie hier onder ons, tussen ons kan vind nie, sal ons Hom nêrens vind nie" (p 125).

Müller begin sy boek, na die inleidende gedeelte, met Hoofstuk 1: Daar staan Job toe op (p 13): "Ná my radio-ervaring, waarvan ek hierbo geskryf het, gebeur dit heel spontaan dat ek ' $n$ ontmoeting met Job het. Ek was in daardie tyd besig om saam met ' $n$ Bybelstudiegroep in die boek Job te lees en daar staan hy as't ware uit die dood uit op. Ek het nooit gedink dat die Here vir my in Job sou opstaan nie, maar in daardie tyd was dit presies my ervaring. In ' $n$ eenvoudige gesprekskring het die Here op ' $n$ onverwagse manier en plek weer lewendig geword en my lewe binnegetree. Die opgestane Here in die gedaante van Job!"

Hierdie beskrywing plaas die opstanding binne ons daaglikse subjektiewe ervaring. Anders gestel: die opstanding word hier gebruik as metafoor om 'n subjektiewe ervaring te beskryf.

Waarom voel ek ongemaklik met so ' $n$ stelling? Omdat die hele gebeure beperk bly tot die horison van die individuele subjektiewe ervaring en slegs daar plaasvind. Ek wil die Nuwe Testament ernstig neem as dit die subjek plaas in ' $n$ intersubjektiewe of persoonlike verhouding met God: dat die opgestane Jesus self 
verskyn het en mense aangespreek het met gesag sodat hulle Hom moes antwoord. Dit was ' $n$ intersubjektiewe ontmoeting of gebeure.

Müller bespreek sy ervaring, tweedens, nie in historiese kategorië (verlede, hede toekoms) nie. Die onderliggende denkpatroon word elders in sy boek verder toegelig. Oor die tydsverloop sê hy byvoorbeeld op bladsy 117: "Die opstanding is God se nuwe begin weer en weer....' het voorgoed begonnen begin' .... Die finale begin van die begin." Die formulering op bladsy 13 "...dat die Here vir my in Job sou opstaan...het die Here op "n onverwagse manier en plek weer lewendig geword en my lewe binnegetree..." dui op so "n altyd-herhalende begin. Elke subjektiewe ervaring van die teenwoordigheid van God kan as 'n opstanding van die Here beskryf word, waarin Hy weer lewendig word.

Die eskatologiese denke wil egter die klem plaas op die werklikheid wat veel groter as ons subjek is en nie eers deur ons ervaring tot werklikheid word nie. God is met die wêreldgeskiedenis op pad, en die opstanding is " $n$ keerpunt daarin. Die hemelvaart bevestig sy kosmiese heerskappy. Die "reeds" en "nog nie" van die eskatologie, Moltmann se teologie van hoop, wat die opstanding sien as gebeurtenis wat die geskiedenis oopbreek na die toekoms - soos in Müller se aanhaling van Bosch geformuleer - dit alles sou ek baie meer van wou lees in sy boek.

Die eskatologie verstaan die Christusgebeure as een-vir-almal en eens-vir-altyd. Dit het gebeur op ' $\mathrm{n}$ dag in die geskiedenis. In hierdie gebeure en die nawerking daarvan bly 'n mens (soos Job) mens en God alleen is God. Die Here staan nie in Job op nie, Hy word nie vir my lewendig nie. Deur die geloof en deur die Heilige Gees en die Woord kry ek deel aan sy opstanding. Die Here word nie lewendig as dit gebeur nie, dit is ek wat tot nuwe lewe gewek word.

Gevolgtrekkig ten opsigte van Müller se siening van die eindtyd: $\mathrm{Na}$ my mening het Müller die opstanding tot so " $\mathrm{n}$ mate binne die subjektiewe ervaring geplaas dat die eindtyd, die hoop op die koms van ' $n$ nuwe hemel en ' $n$ nuwe aarde, vervaag. ' $n$ Simboliese siening van die opstanding kan net soveel as ' $n$ ortodokse siening ' $\mathrm{n}$ verskraling wees. Die opstanding is meer as ' $\mathrm{n}$ simbool. Dit verander die werklikheid. Die simboliese neig na die ou vergeestelikte spiritualiteit. Die bal rol te los oor Platland, hy verskyn en verdwyn te skimagtig. Die metafore is te subjektief. Te min. Die fisieke en die historiese hoort daarby. Dan kry die 
subjektiewe, persoonlike geloofservaring sy plek in, en deel aan, ' $n$ pragtige, groot, veelkleurige geheel.

\section{c) Die fisieke opstanding}

Die fisieke, soos die historiese, opstanding van Jesus speel in die herontdekking van die eskatologie ' $n$ sentrale en deurslaggewende rol.

Die term fisies/fisiek is vir Müller 'n probleem. Hy weier om te antwoord op die vraag of Jesus fisies/fisiek opgestaan het: "Jesus se opstanding is in misterie gehul. ' $\mathrm{n}$ Kategorie soos 'fisiek' of 'letterlik' kan nie gebruik word nie” (p73).

Ek sou versigtig omgaan met die woord misterie in die verband. Die Nuwe Testament polemiseer teen die misteriegodsdienste van daardie tyd en gebruik die woord nêrens in verband met die opstanding nie. Die sinoptici gebruik dit eenmaal (Mt 13:11 $=\operatorname{Mk~4:11=Lk~8:10)~in~die~gangbare~betekenis~van~daardie~tyd,~}$ naamlik die kennis wat die dissipels as ingewydes of geroepenes het wat ander mense op daardie stadium nie het nie.

Wat Paulus betref is die misterie geopenbaar en daarom bekend of kenbaar. Dit word verkondig aan alle mense. Die misterie is dat ons deur die kruis verlos word, deur genade, en dat dit vir almal bedoel is. Jy hoef nie te vorder tot op " $n$ sekere vlak om dit te verstaan of te ontvang nie. Die slimmes en rykes en goeies mis dit omdat hulle dink hulle het die genade nie nodig nie. Die armes en die sondaars is meer ontvanklik, en (daarom?) gaan die tollenaars en hoere die Fariseërs en Skrifgeleerdes voor in die Koninkryk. Die misterie is juis dat dit histories en konkreet en eenvoudig genoeg is vir die nie-geleerdes. So word die konsep "misterie" ingebind en opgeneem in die boodskap van Jesus.

Soms word die konsep misterie in die gesprekke wat om die huidige stryd gevoer word, skynbaar meer Grieks as Nuwe Testamenties gebruik, as gesê word dat die kritici nie die wetenskap van die teologie verstaan nie.

Müller beklemtoon die diskontinuïteit tussen die aardse Jesus en die opgestane Jesus, byvoorbeeld dat Maria Jesus nie dadelik herken het nie (sien pp 56, 60, 72). Hy beweeg deur ' $n$ geslote deur, hy verskyn en verdwyn. Müller beklemtoon verder die verskil tussen die opwekking van Lasarus en die opstanding van Jesus: "Lasarus se opstandingsliggaam is ' $\mathrm{n}$ histories-liggaamlike, of ' $\mathrm{n}$ histories- 
fisieke een. Dit is 'n liggaam wat molekule vir molekule weer uit die graf gekom het” ( $p$ 97).

Müller voel die aandrang op ' $n$ belydenis van die fisieke opstanding beweeg verby die beskikbare gegewens en doen dan afbreuk daaraan: "Die sober en ekonomiese taal waarin die belydenisskrifte oor die opstanding van Christus praat, gee juis ruimte aan hierdie misterie. Woorde wat bygevoeg word, loop die gevaar dat die Jesusgebeure vereng word om in te pas binne die kategorieë van die Lasarus-gebeure. Dus, wanneer ' $n$ konsep soos "histories-liggaamlik" bygetrek word om die aard en betekenis van Christus se opstanding te verduidelik, word sy opstanding juis daardeur ontsettend versluier en ontdaan van die onsêbare geheimenis" (p 98).

Die leser sou kon aanvaar dat Julian Müller volledig pas in Piet Muller se beskrywing van die postmoderne groep wat "die letterlike verstaan van Jesus se...opstanding en hemelvaart verwerp", maar kom dan by die gedig van die Engelse digter John Updike, wat Müller met instemming aanhaal. Updike sê van Jesus presies dieselfde, en nog meer fisiek, as wat Müller van Lasarus sê (p 27):

Let wel: het Hy hoegenaamd opgestaan

was dit as sy liggaam;

as selontbinding nie omgekeer het nie,

die molekule nie herskik het nie,

die aminosure nie herstel het nie,

sal die kerk ten gronde gaan.

Updike het juis die fisieke opstanding van Jesus sterk beklemtoon! Daaruit moet ' $n$ mens aflei dat Müller, ten spyte daarvan dat hy die aandrang op " $\mathrm{n}$ eenvoudige "Ja" op die vraag oor die fisieke opstanding afwys, tog ook nie eenvoudig "Nee" kan antwoord nie. Die eenvoudige antwoord op die vraag moet nog uitkristalliseer, wat beteken dat daar nog gesprek nodig is.

Vir my is die verrassende dat die fisieke liggaam van Jesus opgeneem word in die opgestane liggaam, in dit wat meer is. Die kontinuïteit of identiteit tussen ons huidige fisieke liggaam en die verheerlikte opstandingsliggaam word saam met die diskontinuïteit bely. Die fisieke ooreenkomste en die fisieke verskille is albei waar. Daarom kan ek op die vraag oor die fisieke en historiese opstanding met vrymoedigheid "Ja" antwoord, met die opmerking daarby dat dit ons ervaring van ruimte en tyd insluit en terselfdertyd transendeer. 
Dit is baie belangrik dat daar - saam met die belydenisskrifte gebly word binne die raamwerk waarin die Bybel oor sulke sake praat, anders verval ons in dwalings. Maar juis die wyse waarop Bybelskrywers die liggaamlike en historiese opstanding beklemtoon laat ons verstaan dat hulle baie goed besef het dat hier iets unieks en deurslaggewend gebeur het, wat persoonlike en kosmiese betekenis het. Die Apostoliese belydenis praat - ook op sober en ekonomiese wyse - van die opstanding op die derde dag, wat tog histories is. En van die opstanding van die vlees, wat tog die fisieke liggaam is. Ons kan tog nie anders as om woorde by te voeg nie? Anders moet ons heeltemal stilbly! Müller voeg tog self woorde by as hy sy siening van die opstanding verduidelik!

Myns insiens is die diskontinuïteit wat Müller beklemtoon reg, maar daarmee saam is die kontinuïteit - die opstanding van die vlees - paradoksaal en tegelykertyd net so belangrik. Die meerkantigheid van die opstanding sluit die fisieke en die letterlike in, nie uit nie.

Müller voel dis ' $n$ "oneindige inperking en ten diepste ' $n$ verwerping van die betekenis van die opstanding, wanneer ons met sulke eng kategorieë daaroor dink en praat". Maar dit kan ook ' $n$ inperking wees as ons sulke kategorieë spesifiek uitsluit en verwerp, asof dit nie ook deel is van die geheimenis nie.

Gevolgtrekking oor Müller se siening van die fisieke opstanding: Hy beklemtoon die misterie, die diskontinuïteit met ons fisieke bestaan. Hy weier om met ' $n$ eenvoudige $J a$ te antwoord op die vraag na die fisieke opstanding - maar hy kan ook nie met ' $\mathrm{n}$ eenvoudige Nee antwoord nie, soos blyk uit sy aanhaling van Updike.

Die vierde stelling wat gemaak is, is dat die Sendingwetenskap gewoonlik ' $n$ ander benadering tot hierdie vrae het as die Pastorale Teologie. Hierdie stelling is toegelig met drie voorbeelde: die onderskeie sienings van geskiedenis, die eindtyd en die fisieke werklikheid. Elkeen van hierdie sake is bespreek.

Aan die einde van die bespreking van die vierde stelling bied ek dan die volgende gevolgtrekking: As 'n mens Müller se boek oor die opstanding, veral sy sienings van die geskiedenis, die eindtyd en die fisieke opstanding, vergelyk met prominente neigings in die Sendingwetenskap, dan lyk dit asof iemand soos Bosch, na die herontdekking van die eskatologie, 'n ander soort postmodernisme in gedagte het as Müller. Die Sendingwetenskap neig om, naas die 
mens self, belang te stel in die werking van magte wat groter is as die indiwidu en sy simbole. Dit is mooi verwoord in ' $n$ beskrywing van die Nederlandse Sendingwetenskaplike Hendrik Kraemer deur E Jansen Schoonhoven (1970:13): "Maar dat waarop het aankomt, ligt achter en onder en boven alle theologische begrippen, en dat was het, waardoor de bijbel hem overweldigd had en steeds opnieuw overweldigde: de werkelijkheid van God, de werkelijkheid van de mens en de wereld, de werkelijkheid van hun verbroken en in Christus herstelde verhouding. Daarom kon een hartstochtelijke belangstelling voor de mensen, voor de culturen, voor de religies, voor de wetenschap, samengaan met een hartsochtelijke belangstelling voor de Evangelie, voor de zending, voor de kerk. In zijn bijbels realisme werden deze interessen verbonden."

Vyfde stelling: Ons kan die strewe na presiese formulerings nie ontwyk nie, maar die lewe kom voor die leer en die gegrepenheid deur God dra die aangesprokenheid deur die verhaal en nie andersom nie

Müller maak beswaar teen die aandrang op presiese formulerings, teen die vereiste dat jy "presies reg glo .... as jy dalkies nie die regte woorde in jou belydenis gebruik nie, is jou geloof onvoldoende en dan dop jy die toets" ( $p$ 8). Hiervoor het " $n$ mens begrip. Dit is duidelik dat ons geloofsinhoud nie ' $n$ saak is wat vir altyd klaar en presies geformuleer kan word nie - die Bybel self gee verskillende formulerings, selfs van die tien gebooie.

Tog is Müller nie gekant teen noukeurige taalgebruik nie. Hy gebruik selfs die woord "presies" as hy verklaar dat hy die boek Opstanding geskryf het "om vir myself rekenskap te gee wat ek presies glo" ( $p$ 9). Hy motiveer waarom hy die woord "fisiek" gebruik en nie "fisies" nie (p 17). En hy volg die riglyn credo ut intelligam ( $\mathrm{p}$ 68). "Daar is " $\mathrm{n}$ dringende behoefte om in taal, metafore en kategorieë te praat en te preek om hedendaagse mense by te staan in hulle verstaan van die evangelie..." (p 83).

Ons dilemma blyk op bladsy 115: hy probeer om "taal te vind vir die uitdrukking van my eie opstandingsgeloof in hierdie postmoderne tyd", maar wil nie verval in ' $n$ nuttelose gedebatteer nie. "Wat ek probeer doen, het niks te doen met die pogings van die ortodoksie en fundamentalisme om met korrekte formulerings die 'waarheid' te probeer beskerm nie." 
Tog moet daar debat gevoer word. Müller het die boek geskryf om vir homself rekenskap te gee wat hy "presies glo" - maar hy het dit gepubliseer om dit ook aan die lesers oor te dra. Dit is egter nie so maklik om aan die einde te weet wat hy presies glo nie! Daar moet steeds probeer word om dit noukeurig te formuleer, nie om die "waarheid" te probeer beskerm nie, maar om getrou te bly aan dit wat ons glo.

1. Die betekenis van die strydvraag vir die roeping van die teologiese fakulteit in die Suider-Afrikaanse konteks

Ons siening van die opstanding is bepalend vir die rol en posisionering van die teologiese fakulteit in die Suider-Afrikaanse konteks. Slegs enkele kort opmerkings kan hier gemaak word. Dit gaan oor twee sake: die kwessie van kerkeenheid en die wyse waarop die fakulteit haarself posisioneer.

\section{Kerkeenheid}

Hoe vind ons kerkeenheid as daar sulke sterk polarisasie in een van die lidkerke is? En hoe verander dinge as die hele NG familie verenig? In die VG Kerk, die NGKA en die RCA is daar nog meer strominge as in die NG Kerk alleen.

In daardie kerke is daar "fundamentaliste", maar hulle gebruik die Bybel gewoonlik minder rasionalisties en meer emosioneel of intuitief, en allegories. Hier is korrekte proposisies en noukeurige formulerings van min belang. Dit gaan oor sterk emosionele ervarings wat ' $n$ mens meevoer.

As die NG Kerk-familie verenig, kry ons in een kerk byeenkomste van Bybelwetenskaplikes soos die aangeklaagdes en hulle aanklaers - goed befonds, met elektriese lig en skootrekenaars, geleerde individue - asook deurnag revivals in dofverligte sale, waar arm gelowiges in groot getalle saamtrek. Daar word die Bybel afwisselend gebruik vir allegoriese eksegese en as ' $\mathrm{n}$ drom wat met die een hand vasgehou word, en met die ander hand ritmies geslaan word totdat ' $\mathrm{n}$ toestand van milde ekstase bereik word en mense eenwording met die karakters van die Bybel ervaar: met Elia wat onder die bos lê en wens om te sterwe, maar deur die engel versterk word vir die land pad wat voorlê. Die gedagte dat daar dalk sinergie tussen hierdie groepe bewerk kan word maak die lewe in SuidAfrika so opwindend. 
Maar meer nog: Met kerkeenheid kom die globale Noord-Suid verskille tot binne in die kerk. Andrew Kirk, " $n$ teoloog wat ' $n$ leeftyd aan teologiese opleiding in Suid-Amerika en Engeland gewy het, het ' $n$ fundamentele verskil in die uitgangspunte van die teologië in die Noorde en die Suide waargeneem. In die Noorde word die teologie se geldigheid getoets aan die vraag: voldoen dit aan die vereistes van die wetenskap? In die Suide, waar die teologie van bevryding die paradigma bepaal, is die fokus op "its ability to inspire people to be agents and embodiments of the life of God's new creation in Jesus Christ" (Kirk 1997:7).

Dit geld ook vir ons fakulteit se posisie in Afrika. By die fakulteit word dikwels geredeneer oor die vraag oor die wetenskaplikheid van ons teologie, eerder as oor ons rol in die hantering van die groot probleme van Afrika. Dit is belangrik dat Müller by geleentheid beswaar gemaak het daarteen dat ons tyd opgeneem word deur hierdie stryd en nie deur die nood om ons nie.

Kerkeenheid vereis dat die middelpuntvlietende kragte in toom gehou word deur hulle te identifiseer en te beskryf op ' $n$ wyse waarmee almal - ook die voorstanders van 'n bepaalde stroming kan saamstem. Ek hoop dit is wat ek hier met Julian Müller se boek gedoen het, al stem ons nie oor alles saam nie.

Die posisionering van die fakulteit

Die stryd wat in hierdie artikel bespreek is, is moeilik te posioneer in die groter teologiese wêreld.

Dit kan nie maklik in die sogenaamde Suide of in die Afrikakonteks geplaas word nie, omdat dit min te doen het met die vernietigende probleme van armoede, MIV/vigs, korrupsie en die agteruitgang van die natuurlike hulpbronne.

Dit pas ook ongemaklik in die internasionale postmoderne debatte, want daar, soos Peters opmerk, is dit die postmoderne denke wat daartoe lei dat die teologie met die vraag gekonfronteer word of Jesus werklik uit die dood opgestaan het.

Dit is dalk eerder ' $n$ stryd wat hoort binne die Afrikaanse kulturele en kerklike wêreld. Dit is juis binne hierdie konteks wat Müller sy teenstanders plaas.

Die kategorië wat die joernalis Piet Muller bied is wel populêr, maar van weinig nut indien ons ons wil plaas in die groter Afrikakonteks. Hy praat van pre-modern, modern en postmodern. Die 
benaminge van die strominge veronderstel ' $n$ vooruitgang van oud en uitgediend na nuut en beter, wat misleidend is. Die teologie in die VG Kerk is ook nie so konserwatief as wat Piet Muller dink nie. Die bevrydingsteologie en die Afrika-teologie ("African Theology") sorg hier vir ' $n$ heel ander dinamika as in die NG Kerk. Ons moet sulke oorvereenvoudigde kategorisering van mekaar - en onsself - vermy.

$\mathrm{Na}$ my mening is die eintlike stryd nie tussen modernisme en postmodernisme nie. Die vraag is watter soort postmodernisme (in die sin van dit wat in die plek van die modernisme moet kom) vir die Afrikaanse teologie van waarde sal wees in ons soeke na ' $n$ sinvolle rol in Afrika. ' $n$ Postmodernisme wat slegs probeer om ' $n$ verbygegane fase op te ruim is, soos Van Peursen opmerk, self slegs ' $n$ tussenfase. Die vraag is wat kom daarna. Ricoeur en Derrida lei tot ander aksente as Levinas en Hannah Arendt. Dit is belangrik dat Müller sy posisie intussen meer spesifiek as "post-foundational" beskryf het.

Van wesenlike belang bly steeds dat die Afrikaanse teologie toegang moet probeer kry tot die leefwêreld van Afrika, die kontinent waarin ons moet leef. Dat ons na die saak self gaan, die teologie en denke van die kerke in Afrika, en dit probeer hoor soos wat dit gehoor wil word. Dan sal die opstanding van Jesus op nuwe maniere vir ons belangrik word.

\section{Literatuurverwysings}

Bosch, D J 1994: Transforming Mission. New paradigms in Theology of Mission. New York: Orbis Books.

Kirk, A 1997: The theology of Mission and the mission of theology. Valley Forge: Trinity Press International.

Kraemer, H 1932: Het boek van De Kat Angelino in De Opwekker 77(3), 86179 (ook in Koloniale Studien, Junie 1931).

Küng, H 1981: Existiert Gott? Munchen: Chr Kaiser Verlag.

Le Roux, J H 2006. Die toekoms van die teologie aan die Universiteit van Pretoria. Ongepubliseerde uitdeelstuk by gesprek van NG-dosente.

Louw, NP van Wyk 1986: Maskers van die erns, in Louw, NP van Wyk: Versamelde prosa 2. Kaapstad: Human en Rousseau, 3-5.

Loader, J 1996: 'n Hervormde tradisie as heelmiddel in HTS 52(4), 566-588.

Müller, J 2006: Opstanding. Wellington: Lux Verbi.BM.

Muller, P 2006: Drie strominge bedreig kerkeenheid oral in Rapport Perspektief, 2 Julie, 2. 
Peters, T, Russel, R B \& Welker, M (eds) 2002: Resurrection. Theological and Scientific Assessments. Grand Rapids: Eerdmans.

Schoonhoven, E J 1970: Inleiding tot: Schoonhoven en Graaf van Randwijck, reds, Uit de nalatenschap van van Dr H Kraemer. Kampen: Kok.

Van Peursen, C A 1995: Na het postmodernisme. Kampen: Kok Angora.

Van Niftrik G C 1971: Het bestaan van God in de kentering van deze tijd. Den Haag: J N Voorhoeve.

Welker, M 2001: Der Wirklichkeit der Auferstehung in Eckstein, H-J \& Welker, M (hrsg): Der Wirklichkeit der Auferstehung. Neukirchen-Vluyn, Neukirchener Verlag, 311-332. 